\title{
Financial Benefits of Box Hive and the Determinants of Its Adoption in Selected District of Ethiopia
}

\author{
Workneh Abebe Wodajo \\ Ambo University, Ethiopia
}

\begin{abstract}
Though beekeeping is a common farming enterprise and income generating activity in Atsbi Wemberta district, and promotional efforts have been made to improve it, no systematic study has been undertaken to evaluate the promotional efforts and people's response to it. The objectives of this study were to identify determinants of improved box hive adoption by the beekeepers; and to analyze financial benefits from adopting improved box hive technology. It was found that credit, knowledge, education level of household head, perception and visits to demonstrations positively and significantly influenced adoption of box hive. Hence, Linking honey producers to stable and reliable markets and following a participatory value chain based approach; promoting private entrepreneurs to provide additional services for value addition; promoting farmer-to-farmer knowledge sharing; and encouraging farmer groups create a learning environment are some initiatives that could go a long way in the sustainable development of this important economic sub-sector.
\end{abstract}

Keywords Adoption, Determinants, Financial, Improved Box Hive

\section{Introduction}

Livestock is an important economic sector in Ethiopia, which contributes to economic development. Ethiopia is generally considered to have the largest population of livestock of any country in Africa[1].Livestock contribute to $20 \%$ to Ethiopia's GDP and livelihoods of $60-70 \%$ of the population[2]. The author further stated that apiculture, which is one of the important livestock sub-sectors, contributes significantly to improvement of the livelihoods of the nation's population.

There is no well-documented evidence that indicates when and where beekeeping practice started in Ethiopia. According to[3], it had started in the country between 3500-3000 B.C. The country has a high potential for beekeeping, as the climate is favorable for growing different vegetation and crops, which are a good source of nectar and pollen for honeybees. Due to suitable natural environment of the country a large number of honeybee colonies, estimated at about 10 million, exist in the country[3].

Ethiopia produces around $23.6 \%$ and $2.1 \%$ of the total African and world's honey, respectively. It is the leading honey producer in Africa and one of the ten largest honey-producing countries in the world[4]. It is also one of the four largest bees-wax producing countries in the world. In Ethiopia, beeswax is one of the 12 major exportable

\footnotetext{
* Corresponding author:

workneh abebe@yahoo.com (Workneh Abebe)

Published online at http://journal.sapub.org/economics

Copyright (C) 2011 Scientific \& Academic Publishing. All Rights Reserved
}

agricultural products and an estimated one million farmers are engaged in beekeeping[5-7]. The country produces about 28,500 tons of honey and 5,000 tons of beeswax annually[8].

Beekeeping in Ethiopia plays an important role in income generation for beekeeper farmers. An average of 420 million Eth. Birr is obtained annually from the sale of honey, both in local and world markets. Honey production of the country meets beverage requirements of the urban and rural population. It is also demanded for its nutritional and medicinal values. The other hive products such as beeswax, royal jelly, propolis, and bee venom have high demand globally.

In addition, honeybees play a great role in pollinating plants and contribute to increased crop yield. Self-sterile plants (cross pollinated) require pollinating agents to maintain viable seed. According to[9] honeybees can increase the yield of Citrus sinensis by $30 \%$, water melon by $100 \%$ and tomatoes by $25 \%$.[10] also reported that onion yields increased by $94 \%$ due to honeybee pollination.

The Ethiopian government, realizing the potential of beekeeping sub sector of the country, established demonstration stations at Holeta, Nekemt and Jima in 1965. The main objectives of the demonstration stations were to introduce imported improved beekeeping technologies (box hives, casting mold, honey extractor, honey presser, smoker, water sprayer, veil, glove, etc) to the beekeepers and to offer beekeeping training for farmers and experts. According to[11], formally organized beekeeping extension started in 1978. While the demonstration stations mainly targeted beekeepers located in the vicinity of the stations and their coverage was small, formally organized extension has been aiming for a wider coverage. Currently, different private 
organizations are also engaged in the production of beekeeping equipment.[12] showed that adoption rate of improved box hives is low in the country and highlighted the importance of investigating factors influencing the adoption of improved box hives. Obviously, there is no information currently available on the determinants of the technology adoption, and the financial benefit of adopting the box hive technology

Identification of the factors that influence the adoption of a technology, positively or negatively, are important for policy makers, researchers and organizations involved in beekeeping development programs to get insights into the adoption of improved box hive, which in turn would help them to suitably modify the strategies for improved uptake.

To fill this knowledge gap, this study was designed with the specific objectives of:

- Identifying the determinants of improved box hive adoption by the beekeepers and,

- Analyzing the financial benefits from adopting improved box hive technology.

\section{Research Methodology}

\subsection{The Study Area}

Atsbi Wemberta district is located in Eastern zone of Tigray Region at about $65 \mathrm{~km}$ north east of Mekele, the regional capital city. It has an altitude at Dega (highland), which ranges from $2400 \mathrm{~m}$ to 3000 masl and at weinadega (midland) ranging from $1800 \mathrm{~m}$ to 2400 masl. The District has a total area of about 1223 sq. km, with $70 \%$ and 30\% Dega and Weina $\operatorname{deg} a$, respectively. The average temperature of the area is $18^{\circ} \mathrm{C}$. Rainfall is usually intense and short in duration, with an annual average of about $667.8 \mathrm{~mm}$.

Atsbi Wemberta has a total human population of 112,639, of which 55,359 (49.15\%) and 57,280 (50.85\%) are male and female, respectively. The urban and rural population is 9609 and 103,030 , respectively[13].

Atsbi Wemberta is one of the districts of Tigray Region with a high potential for beekeeping development. The woreda (district) has 16,915 honeybee colonies[13], making it one of the high potential areas for developing beekeeping in the region as well as in the country. All beekeepers of the district were only using traditional beehives until eight years ago. Improved box hive was introduced into the district in 1998, 30 years after its introduction to the country. Even though the duration of its introduction to the district is short the promotion of the technology is encouraging and currently there are 5716 of such hives in the woreda. Improved and traditional beekeeping practices are found to co-exist in the area. Highland areas are used for traditional beekeeping and the mid-lands for improved beekeeping. According to the beekeepers and bee expert of the district, the highland is not suitable for improved box hive as it is too cold and the honeybees cannot resist the cold in the box hive. This results in high rate of absconding of honeybees and low yield.

\subsection{Sampling Techniques}

Purposive sampling was employed to identify Peasant Associations in which improved box hive was promoted. Based upon the number of beekeepers and honeybee colony population, four Peasant Associations (Hayelom, Dibab-Akorein, Barka-Adisabiha and Michael-Emba) with high beehives population were selected purposively (Fig 1). In the selected Peasant Associations, the beekeepers were stratified into adopters and non-adopters ${ }^{1}$ of improved box hives. The total sample size for the study was 130 beekeepers. Based on the probability proportional to size principle, 45 adopters and 85 non-adopters were selected for the study through systematic sampling method.

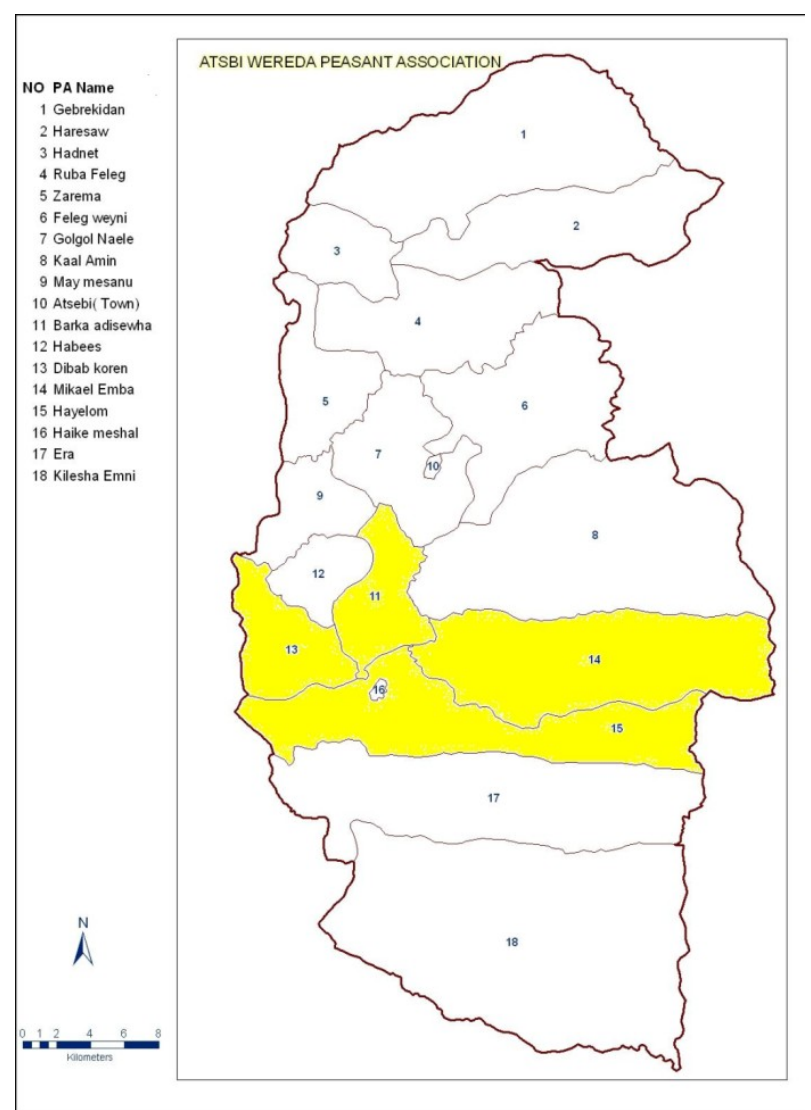

Figure 1. Map of Atsbi Woreda with sampled PAs.

\subsection{Data Collection and Analysis}

A full understanding of the complexities involved in the adoption of technologies and the impacts they have can only be achieved by mixing methods, such as quantitative surveys, qualitative interviews, focus group discussions, etc[14]. The required data were collected from beekeepers and extension workers of the district. Structured interview schedule was prepared and pre-tested to include all quantitative data pertaining to the proposed study. For obtaining the relevant information, personal observations, focus group discussions

\footnotetext{
1 Adopters are those beekeepers who used improved box hive for at least two years and non-adopters are beekeepers who did not use improved box hives during the study period.
} 
and personal interviews were conducted with beekeepers, extension workers and bee experts.

Enumerators who have know-how on beekeeping were recruited and trained to collect data using the interview schedule, under the supervision of the researcher. The researcher monitored the enumerators during data collection. Secondary data were collected from different sources such as books, research publications, journals, office reports, Internet etc.

The required data for partial budgeting, such as prices of improved box hive, pure bees-wax and accessories were collected from the District ARD office. Honey yield, price, feed cost, labor cost and traditional hive cost were collected from respondents.

\subsection{Data Analysis}

The tools used for data analysis and presentation were descriptive statistics such as percentages, frequencies, mean and standard deviations; t-test and $\chi^{2}$ were employed to test the significance of continuous and discrete variables, respectively. For assessing financial benefit of improved box hive, partial budgeting ${ }^{2}$ was employed.

Many models used in adoption studies fail to meet the statistical assumption necessary to validate the conclusions based on the hypothesis tested and they recommend the use of qualitative response models[15].Logit and probit models are mainly used in adoption studies. However, the output of Probit and logit models is usually similar[16].Even though their outputs are similar, one advantage that logit has over probit is that it can provide an additional interpretation i.e. the factor change in the odds of an even occurring. A binary logit model was used to identify the determinants of improved box hive adoption in this study. Following[17]the model is specified as:

$\operatorname{Ln}[\mathrm{p} /(1-\mathrm{p})]=\mathrm{b}_{0}+\mathrm{b}_{1} \mathrm{x}_{1}+\mathrm{b}_{2} \mathrm{x}_{2}+\mathrm{b}_{3} \mathrm{x}_{3} \ldots \mathrm{b}_{16} \mathrm{x}_{16}+\mathrm{e}$

The dependent variable is the natural log of the probability of adopting improved box hive (P), divided by the probability of adopting (1-P). The model was estimated using the maximum likelihood method. The variables presented below were used in the model

The independent variables that influence the adoption of improved box hive technology are selected based on literatures and personal experience. It is discussed and hypothesized as follows:

Age (AGE): It is a continuous variable and measured using completed years of life. Literature reveals that young people are more flexible in deciding for change than aged people[18].Therefore, it was anticipated that young people adopt the improved box hive more than elders.

Family size (FAMLSIZ): It is a continuous variable and was measured taking total number of household members. Farmers with large family size might significantly adopt the

\footnotetext{
2 A partial budget is a technique for assessing the benefits and costs of a practice relative to not using the practices. It takes into account only those changes in costs and returns that result directly from using a new practice.
}

technology, to satisfy the need of their family. Hence, it was hypothesized that household with large family would adopt the technology more.

Education of household head (EDUCATI): Improved box hive technology utilization involves technical applicability;[15] noted that education improve the decision making process and thereby influence the level and/or composition of anther inputs. Hence education would increase the understanding of the technology and anticipated to increase adoption. This variable was measured based upon formal years of schooling attended by the respondents.

Use of credit (CREDIT): lack of initial capital hinders the farmer from adopting the technology, particularly resource poor farmers. It is dummy variable and was measured using 1 if the respondent receives credit from credit institution when they require 0 , otherwise. As receiving and utilizing credit for intended purpose, can increase the adoption of improved box hive technology, it was expected that receiving credit and adoption of the technology has positive relationship.

Extension contact (EXTCONTA):[15] noted that extension efforts increase the probably of new technology by increasing the stock of information pertaining to modern production increment. It is dummy variable and was measured using 1 if the beekeeper has contact with extension agent and 0, otherwise. Effective utilization of improved box hive technology requires close follow up of the extension workers. So, it was hypothesized as beekeepers who have contact with extension agent would adopt the technology more.

Apiary visit (VISTDEM): A study by[19], confirmed that farmers characteristics such as participation in field days and demonstration enhance adoption of farm technology. Visiting apiary sites of other beekeepers or demonstration site help the beekeeper to develop his/her insight in beekeeping. It is dummy variable and was represented using 1 if the beekeepers visit apiary/demonstration site and 0 , otherwise. It was hypothesized that beekeepers those who visit apiary/demonstration site adopt improved box hive more.

Market for the products (MKTAVAIL): Availability of the market for the hive products determines the decision of adopting the technology. It is dummy variable and was measured using 1 if the respondent has market for their product and 0 , otherwise. It was anticipated that there is positive relationship between market and adoption of the technology.

Beekeeping training (BKTRAIN): It is dummy variable and was measured using 1 if the respondent has got beekeeping training and 0 , otherwise. Training is very important to create awareness on the technology as well as to make the beneficiary more productive.[20]also stated that training might have inculcated technical competency, more exposure to the subject matter and convinced to adopt the improved technologies in the farms. It was hypothesized that obtaining training on the technology has positive influence on the adoption of the technology. 
Perception: The rate of adoption is influenced by the farmers ' perception of the characteristics of the innovation[21]. Perceived relative advantage of improved box hive and its relative disadvantage measured using five point scales. It was hypothesized that the total positive results of the perceived attributes (advantages and disadvantages of the technology) affects adoption positively.

Knowledge of the technology: As noted by[22] Knowledge is the function in which an individual is exposed to the innovation's existence and gains some understanding of how it performs .Having knowledge of the technology is crucial for effective and efficient utilization of the technology. So, it was hypothesized that beekeepers who have sufficient knowledge of the technology adopt the improved box hive more. This variable was measured by inquiring the respondents, five practical questions of improved box hive.

\section{Result and Discussion}

\subsection{Demographic and Socioeconomic Characteristics of Sample Respondents}

Table 1 summarizes demographic and socioeconomic characteristics of sample respondents. The mean age of household head for adopters and non-adopters is 42.2 and 47.2 years, respectively, with a significant mean difference at $\mathrm{P}<0.01$. It implies that beekeepers are generally reluctant to experiment with new technology, as they get older[23,24]in their study of adoption of soil and water conservation in Ethiopia also indicated that age of the household head negatively influenced adoption. The mean family size is 6.6 and 5.9 for adopters and non-adopters, respectively again significantly different at $\mathrm{P}<0.05$. This indicates that beekeepers with large family size opt for improved technologies to improve productivity and incomes. Adopting improved box hives also demands additional labor and therefore, households with larger family size are more able to meet these demands[25] documented that highest labor is involved in watching and during swarming times, beehive construction, honey extraction and colony multiplication.

Table 1. Demographic and Socio-economic characteristic of sample respondents $(\mathrm{n}=130)$.

\begin{tabular}{|c|c|c|c|c|}
\hline Variable & Sta. & Adopters & Non-adopters & T-test \\
\hline Age & Mean & 42.2 & 47.2 & $2.621^{* * *}$ \\
Family size & “ & 6.6 & 5.9 & $2.043^{* *}$ \\
BK ex- & “ & 10.7 & 9.5 & $0.941 \mathrm{Ns}$ \\
perience & “ & 0.55 & 0.59 & $0.465 \mathrm{Ns}$ \\
Farm size & “ & 2.7 & 1.1 & $4.239^{* * *}$ \\
Education & “ & 26.8 & 19.01 & $1.388 \mathrm{Ns}$ \\
Apiary size & “ & 4.4 & 3.9 & $0.615 \mathrm{Ns}$ \\
Livestock & “ & 3.2 & 2.4 & $1.590 \mathrm{Ns}$ \\
Bee colony & “ & 16.4 & 13.8 & $4.008^{* * *}$ \\
Perception & “ & 4.7 & 3.3 & $6.054^{* * *}$ \\
Knowledge & & & & \\
& & & & \\
\end{tabular}

*** Significant at $\mathrm{P}<0.01, * *$ Significant at $\mathrm{P}<0.05$, NS- Non- significant
Figures in parentheses indicate percentages

In relation to beekeeping experience, there is no statistically significant difference between adopters and non-adopters. The average years of beekeeping experience of both categories is nearly equal. The education level of adopters of improved box hive is significantly higher than non-adopters of the technology, implying the influence of the variable in improving the knowledge, skill and attitude level of an individual which in turn leads to adoption decisions. The average farm size of adopters and non-adopters is 0.55 ha and 0.59 ha, respectively (both below the national average land holding of $1.5 \mathrm{ha}$ ). This difference was not statistically significant, implying that farm size does not affect adoption of improved box hive in the study area.

Apiary is the place where honeybee colonies are kept on the farm/homestead. The apiary size ranges from $6 \mathrm{~m}^{2}$ to 100 $\mathrm{m}^{2}$ with the mean of $26.8 \mathrm{~m}^{2}$ and $19.01 \mathrm{~m}^{2}$ for adopters and non-adopters, respectively. The difference, which is not significant, indicates that beekeeping activity does not require large or fertile pieces of land. Uncultivated land can also be used. Even landless farmers with small plots of land around homesteads can engage in this activity.

The mean livestock holding, taken as a proxy for wealth status, is 4.4 and 3.9 for adopters and non-adopters, respectively. There is no significant difference in the wealth status of both categories measured by livestock holding, implying that the improved box hive technology is not necessarily suitable only for resource rich households.

The average honeybee colony holding was 3.2 and 2.4 honeybee colonies for adopters and non-adopters, respectively. Having more or less number of colonies did not affect the use of improved box hive, as farming households that decided to use the technology could start by purchasing the colonies. Among the respondents, 29.4\% and $71.1 \%$ of non-adopters and adopters respectively, had got an opportunity to visit an apiary, through extension activities. It is significantly different at $\mathrm{P}<0.01$, showing that farmer-to-farmer exchange of experience and knowledge sharing influences adoption positively.

The difference in positive perception about the technology was also significantly different among adopters and non-adopters. Higher yields and better quality, ease of inspection and, ease of product harvesting are the major relative advantages of improved box hive identified by the majority of beekeepers. On the other hand, high cost, high skill requirement need of accessories, and unavailability of the box hives are the main relative disadvantages of improved box hive as noted by the respondents.

Improved beekeeping technology requires knowledge on its practical activities. The knowledge source could be farm experience, research, extension and NGOs. Five practical questions were provided for beekeepers to identify their level of knowledge on improved beekeeping practices. The mean score of adopters and non-adopters were found to be 4.7 and 3.3 , respectively (Table 1 ). It is significantly different at $\mathrm{P}<0.01$. It is also positively corralled with adoption of 
technology at $(\mathrm{r}=0.472, \mathrm{P}=000)$. This shows that having knowledge of the technology assists adoption of improved box hive. The result is in line with[26] who found that adoption of improved paddy cultivation practices had a highly significant and positive correlation with knowledge of farmers. The finding also agrees with[27] who found that farmers' knowledge of fertilizer use and its application rate positively influenced adoption of farm technology.

With regard to credit, it enables farmers to purchase inputs or acquire physical capital, needed for technology adoption[15]. In other words, the availability of credit facilitates technology adoption. It is more essential for farm technologies like beekeeping, which the farmers perceive the technology to be costly to engage in the activity. The adopters have more used the credit (Table 2). It is also found that it is significantly different at $\mathrm{P}<0.01$. In the study area promotion of the technology is accompanied by credit, as the fact the beekeepers who decide to adopt the technology can get credit.

Table 2. Availability of different services $(n=130)$.

\begin{tabular}{|c|c|c|c|c|}
\hline Variable & Response & Adopters & Non-adopters & $\chi^{2}$ \\
\hline \multirow{2}{*}{ BK training } & Yes & $(75.6)$ & $(5.9)$ & $68.014 * * *$ \\
& No & $(24.4)$ & $(94.1)$ & \\
& Yes & $(84.4)$ & $(42.4)$ & $21.259^{* * *}$ \\
Extension & No & $(15.6)$ & $(57.6)$ & \\
& Yes & $(88.9)$ & $(27.1)$ & $45.036^{* * *}$ \\
Credit & No & $(11.1)$ & $(72.9)$ & \\
& Yes & $(71.1)$ & $(29.4)$ & $20.780^{* * *}$ \\
ApiaryVisit & No & $(28.9)$ & $(70.6)$ & \\
& Yes & $(75.6)$ & $(21.2)$ & $6.253^{* * *}$ \\
Market & No & $(24.4)$ & $(78.8)$ & \\
& & & & \\
\end{tabular}

*** Significant at $\mathrm{P}<0.01$

Figures in parentheses indicate percentages

As shown in Table 2, $84.4 \%$ of the adopters contacted with extension agent. This assists the beekeepers to know more about the technology, which in turn help them to utilize at the technology effectively. The difference is statistically significant at $\mathrm{P}<0.01$. This shows that the beekeepers who frequently visit extension agent get more acquaintance with technology and tends to decide adoption of the technology.

Visiting the apiary helps the beekeeper to learn more about the technology. It also motivates the beekeepers towards adopting the technology. Among the respondents, $29.4 \%$ and $71.1 \%$ of non-adopters and adopters respectively, had got an opportunity to attend apiary visit which was organized by extension (Table 2). It is statistically significantly different at $\mathrm{P}<0.01$. This shows that the beekeepers that got an opportunity of visiting the apiary adopt more the technology. During visiting farmers can clearly understand the advantage of improved box hive from their colleagues. Beekeepers more believe each other than outsiders. Hence, apiary visit is an appropriate means of introducing improved beekeeping technology. The result coincides with findings of[28], which explains that there is significant association between adoption and apiary visit by farmers.

The availability of market for the hive products enhances the adoption of improved box hive. In the study area, $21.2 \%$ of non-adopters and $75.6 \%$ of adopters replied that there was market for their honey. As indicated in Table 2, it is significantly different at $\mathrm{P}<0.01$. The result indicates that adopters have more market for their product. This is mainly due to honey produced in improved box hive has quality and as a result has high demand. It is free of pollen, beeswax, brood and debris.

Beekeeping training develops the beekeepers' self-confidence in the technology. It also increases the productivity of the beekeepers. In the study area, Agricultural and Rural Development and Non- Governmental Organization organized beekeeping training. The trainings were offered on bee management, hive product and colony multiplication. As summarized in Table 2, it is significantly different at $\mathrm{P}<0.01$, which implies developing the skill of beekeeper through beekeeping training enhanced adoption of improved box hive. It was also observed that $24.4 \%$ of the adopters did not get training on improved beekeeping practices. In the other ways, they were provided only the box hives. Under such situation, the beekeeper cannot be the beneficiary of the technology, as it requires skills.

\subsection{Factors Influencing the Adoption of Improved Box Hive}

As indicated in Table 3, $90 \%$ of the total variation for the adoption of improved box hive is explained by binary logit model. The $\chi^{2}$ result shows that the parameters are significantly different from zero at $\mathrm{P}<0.01$ for the adoption of improved box hive. The model correctly predicted sample size of $84.4 \%$ and $92.9 \%$ for adopters and non-adopters, respectively. Among, the explanatory variables, credit, knowledge, education level of household head, perception and visiting demonstration were found to be significant as hypothesized. Age, family size, extension contact, market availability and beekeeping training were insignificant compared to other explanatory variables in the regression. Probably, the lower influence of variables such as beekeeping training, extension contact and availability of market is due to the fact that the high cost of the improved box hive and honeybee colony dominates all other factors. In the other way, though there is extension service and training in the area, it cannot enhance adoption of the technology if the user cannot afford the technology. In relation to marketing, both adopters and non-adopters may have market for their products. This argument was confirmed by group discussion with the farmers.

The explanatory variables that were significantly influencing adoption of improved box hive are discussed here: 
Table 3. Logistic regression for factors influencing improved box hive adoption.

\begin{tabular}{|c|c|c|c|c|c|}
\hline Variables & $\mathrm{B}$ & S.E. & Wald & Sig. & $\operatorname{Exp}(B)$ \\
\hline AGE & -.017 & .045 & .150 & .699 & .983 \\
\hline FAMLSIZ & .382 & .257 & 2.211 & .137 & 1.466 \\
\hline EDUCATI & .446 & .172 & 6.729 & $.009^{* * *}$ & 1.562 \\
\hline PERCEPTION & .252 & .134 & 3.523 & $.061 *$ & 1.287 \\
\hline CREDIT & 2.607 & .968 & 7.251 & $.007 * * *$ & 13.555 \\
\hline EXTCONTA & .805 & .628 & 1.643 & .200 & 2.237 \\
\hline VISTDEM & 2.262 & .905 & 6.247 & $.012 * *$ & 9.598 \\
\hline KNOWLED & 1.656 & .603 & 7.549 & $.006^{* * *}$ & 5.239 \\
\hline MKTAVAIL & 1.257 & .789 & 2.538 & .111 & 3.515 \\
\hline BKTRAIN & 144 & .413 & .122 & .727 & 1.155 \\
\hline Constant & -15.465 & 4.362 & 12.570 & 000 & 000 \\
\hline $\begin{array}{c}-2 \log \text { likelihood } 59.852 \chi^{2} \\
07.857 * * * \text { Predicted adopter } \\
84.4 \%\end{array}$ & $\begin{array}{c}\text { Non-adopter } 93 \% \\
\text { Over all } 90 \%\end{array}$ & & & & \\
\hline
\end{tabular}

$*, * *, * * *$ significant at $\mathrm{p}<0.1, \mathrm{p}<0.05$, and $\mathrm{p}<0.01$

In this particular study, formal credit was considered that was provided in cash. In the study area, improved box hive was perceived as being costly by the beekeepers. Under such circumstances, credit plays a significant role in enhancing the technology promotion. As anticipated, credit affects adoption positively and significantly at $\mathrm{P}<0.01$, the odds in favor of adopting improved box hive increased by a factor of 13.6 for beekeepers who had received credit. Similarly,[29] study on determinants of fertilizer adoption, intensity andprobability of its use and found that access to credit is one determinant of fertilizer adoption and intensity of its use.[30,15,31] also concluded that credit is correlated with the use of improved inputs.

Improved beekeeping technology requires knowledge on the practical aspects. The odds in favor of adopting improved box hive increased by a factor of 5.24 for beekeepers who acquired better skills on improved beekeeping practices. The result is in line with[26] who finds that adoption of improved paddy cultivation practices has a highly significant and positive correlation with knowledge of farmers.[27] also showed that farmers' knowledge of fertilizer use and its application rate positively influenced adoption of high yielding maize varieties.

Education increases the access to information and thereby possible knowledge of beekeepers regarding improved box hive. It also increases the understanding of the technology and facilitates its application[32].As hypothesized, education influences adoption of improved box hive positively and significantly at $\mathrm{P}<0.01$ The odds in favor of adopting improved box hive increased by a factor of 1.56 for beekeepers who had higher education level. The result is also supported by earlier studies of [32] that dealt with factors associated with the adoption of recommended farm practices in a
Nigerian village; [15] which focuses on adoption of agricultural innovation in developing countries; and[31]that identified factors affecting the successful adoption of new technologies by Smallholders.

Apiary is the place where the honeybee colonies are kept, in the farms of model farmers. Visiting the apiary helps the beekeeper to learn more about the technology. It also motivates the beekeepers towards adopting the technology. The odds in favor of adopting improved box hive increased by a factor of 9.6 for beekeepers who had an opportunity of visiting apiary. Beekeepers, who get an opportunity of visiting the apiary and exchanging knowledge and experience with fellow farmers, seem to become more favorable to adopting the technology. Beekeepers trust information from each other more than they do with the outsiders. Hence, apiary visit is an important mechanism to introduce beekeeping technology and induce adoption. The result coincides with[28], who explains that there is significant association between adoption and apiary visit by farmers.

Positive perception of beekeepers about the technology favorably influences adoption decision. The odds in favor of adopting improved box hive increased by a factor of 1.28 for beekeepers who perceived the technology positively.[24] also found that perception influences adoption positively. The result is also in agreement with study of [33] on factors influencing adoption of soil conservation measures in Gununo area of south Ethiopia, which found that the perception about soil conservation problem influenced adoption of soil conservation technology positively. Farmer to farmer experience sharing visits also contributes towards developing positive perception towards an innovation or a new technology.

\subsection{Financial Benefits of Adopting Improved Box Hive}


Yield is an important determinant factor in adopting the technology. The higher the yield obtained from the introduced technology, the easier it is to convince the farmers to adopt the technology. In the study area the minimum and maximum honey yield per annum for improved box hive is 8 $\mathrm{kg}$ and $64 \mathrm{~kg}$, respectively. The mean annual honey yield is $27 \mathrm{~kg}$. It is above the national honey yield average, which is about $20-25 \mathrm{~kg} / \mathrm{hive} / \mathrm{annum}$. The price of one $\mathrm{kg}$ pure honey was 35 Birr at farm gate and 50 Birr at nearby regional town. Hence, a beekeeper could get 945 - 1350 Birr gross benefit per hive/annum.

Table 4. Partial budget for improved box hive and traditional hive.

POSITIVE IMPACTS

\begin{tabular}{|c|c|c|c|}
\hline \multicolumn{2}{|c|}{ Increased return due to adoption (birr) } & \multicolumn{2}{|c|}{ Increased cost due to adoption (birr) } \\
\hline \multirow{5}{*}{ Honey yield sale } & \multirow{5}{*}{945.00} & \multirow{3}{*}{$\begin{array}{c}\text { Transport } \\
\text { interest } \\
\text { Feed }\end{array}$} & 12.55 \\
\hline & & & 23.65 \\
\hline & & & 26.50 \\
\hline & & \multicolumn{2}{|l|}{ Pure bees-wax } \\
\hline & & $\begin{array}{c}\text { Accessory service } \\
\text { charge }\end{array}$ & 19.00 \\
\hline Total Added & 945.00 & Total Added Costs & 219.85 \\
\hline \multicolumn{2}{|c|}{ Reduced Costs due to adoption } & \multicolumn{2}{|c|}{ Reduced Returns due to adoption } \\
\hline Interest & 0.26 & \multirow{3}{*}{$\begin{array}{c}\text { honey yield sale } \\
\text { (from traditional } \\
\text { hive) }\end{array}$} & \multirow{3}{*}{250.00} \\
\hline Feed & 8.70 & & \\
\hline Labor & 5.00 & & \\
\hline $\begin{array}{c}\text { Total Reduced } \\
\text { Costs: }\end{array}$ & 13.96 & $\begin{array}{l}\text { Total Reduced } \\
\text { Returns: }\end{array}$ & 250.00 \\
\hline \multicolumn{2}{|c|}{ TOTAL POSITIVE IMPACTS } & \multicolumn{2}{|c|}{ TOTAL NEGATIVE IMPACTS } \\
\hline \multicolumn{2}{|c|}{958.96} & \multicolumn{2}{|c|}{469.85} \\
\hline \multicolumn{3}{|c|}{ Total positive impacts (958.96) minus Total negative impacts } & $85)=489.11$ \\
\hline
\end{tabular}

The partial budgeting reveals that adoption of improved box hive does result in additional income to the extent of 489.11 Birr in the study area (Table 4), the income being almost three times what one would get from the traditional hive.[28] using partial budgeting analysis in his study also concluded that both the homemade and institutionally made Kenya Top Bar Hive (KTBH) were beneficial and remunerative. He noted that movable top bar hives result in higher net return per colony compared with traditional hives. The national average of KTBH is $10-15 \mathrm{~kg}$ crude honey/hive/an num, which is below the national average of improved box hive (20-25 kg pure honey/annum). Comparison of KTBH with improved box hive was not included in this analysis, as the KTBH were not used in the study area.

Observation and discussions with beekeeper farmers revealed that they were using only one super, while they received two supers. Hence, there is an opportunity to reduce the price of the hive if the beekeepers are provided with one super instead of two supers. Currently, the hive stand of box hive is made up of metal, which also increases the cost of the hive. This can also be made from locally available materials. With the reduction in cost of these two items, the price of the hive can be reduced.

\section{Conclusion and Recommendations}

Both economic and non-economic factors affect the adoption of improved box hive. Hence, for effective utilization of the technology, both factors need equal consideration by policy makers and organizations involved in beekeeping development. In other words, providing the necessary exposure and skills and; institutional support in the form of credit, technology and, market linkages need to be addressed simultaneously.

All the problems faced by beekeepers cannot be addressed by a single organization. Various actors (including research, extension, decision makers, input suppliers, credit agencies and those along the value chain) need to collaborate in search of appropriate solutions and implement them. Following a participatory value chain based approach would go a long way in the efficient development of the sub-sector. Formation of formal or informal actor-alliances with a specific objective will be a useful mechanism to do this. The extension service should take the lead in creating necessary linkages and forming such alliances.

Non-adopters resisted taking any loans due to the high prevalence of honeybees' absconding. There is an urgent need to develop the skill of beekeepers on the management of absconding through organizing practical and hands-on beekeeping training, which will facilitate developing confidence in the technology.

The research and development organizations should identify and document the existing Indigenous Technical Knowledge of beekeepers to integrate it optimally into improved beekeeping practices.

Opportunities to visit other farmers' apiaries were found to significantly influence adoption of improved box hive through developing a positive perception and trust in the technology. This is an effective extension method, hence, extension strategies need to be rethought to design ways of incorporating such effective methods (including field days) while efficiently utilizing available resources. This requires development agents who are competent, knowledgeable and understand the significance of farmer-to-farmer exchange. In addition to the farmers, DAs also need in-service training on improved beekeeping practices to develop practical knowledge of the technology.

Cooperative office of the district ARD and NGOs need to come together to strengthen the existing beekeepers cooperative as they can provide a good learning environment for similar areas. Organizing them to operate in enclosure areas has multiple advantages i.e. apiary can be established in the area and they can also protect and conserve it by planting different bee forages.

\section{ACKNOWLEDGMENTS}

The author would like to thank International Livestock Research Institute (ILRI); Improving Productivity Market Success (IPMS) project for sponsoring the study; Oromia Agricultural Research Institute (OARI) for providing permission to the author for pursuing higher studies; and 
Haramaya University for guiding and supervising the study. Finally but most significantly, I wish to express my appreciation to the Atsbi Wemberta IPMS staff, District Agricultural and Rural Development Office and respondents for their assistance during data collection.

\section{REFERENCES}

[1] Halderman Michael. 2004. "The political economy of pro-poor livestock policy- making in Ethiopia". PPLPI working papar No. 19

[2] Aklilu Yacob. 2002. "An audit of the livestock marketing status in Kenya, Ethiopia and Sudan, Volumes I and II". OAU/Interafrican Bureau for Animal Resources

[3] Ayalew Kassaye. 1978. "Beekeeping Extension in Ethiopia". Unpublished. Holeta Bee Research Center, Holeta

[4] Ayalew Kassaye. 1990. "The honeybees (Apis Mellifera) of Ethiopia. A morphometric study". M.Sc. thesis, Agricultural University of Norway, Norway

[5] Mammo Gebreyesus. 1976. "Practical aspects of bee management in Ethiopia". Proceedings of the first international conference on apiculture in tropical climates, London UK, pp 69-78

[6] Girma Deffar. 1998. "Non-Wood Forest Products in Ethiopia”. EC-FAO Partnership Programme (1998-2000). Addis Ababa . pp. 1-5

[7] MOARD. 2005. Annual Reports, Addis Ababa, Ethiopia

[8] HBRC (Holeta Bee Research Center). 2004. Beekeeping Training Manual. Holeta, Ethiopia

[9] Crane, E. 1990. "Bees and beekeeping: Science, practice and world resources". Comstock publishing associates (cornell university press), Ithaca, New York

[10] Addi Admasu, Ibsa Gizaw, Bezabeh Amsalu and Lemessa Debissa. 2008. "he effect of honeybee (Apis mellifera L.) pollination on the seed yield of Allium cepa in the Ethiopian Rift valley". Ethiopian Journal of Animal Production 8(1), PP. $79-84$

[11] EBA (Ethiopian Beekeeping Association). 2005. "Ethiopia Beekeeping Association annual report". Proceedings of the $4^{\text {th }}$ annual conference of the Ethiopian Beekeepers Association, held in Addis Ababa, Ethiopia, October 25-26, 2005

[12] Kerealem Ejigu. 2005. "Honeybee production system, opportunities and challenges in Enebse sar midir woreda (Amahara region) and Amaro special woreda (SNNPR), Ethiopia”. Unpublished M.Sc. Thesis, Alemaya University, Alemaya

[13] Atsbi Wemberta district ARD ofiice. 2006. Planning document. Atsbi, Tigray region

[14] Dick R., Adato M., Haddad L., and Hazell P. 2004. "Science and Poverty: An Interdisciplinary Assessment of the Impact of Agricultural Research". International Food Policy Research Institute, Washington, D.C

[15] Feder, L., R.E., Just and O. Zilberman. 1985. "Adoption of
Agricultural Innovation in Developing Countries: A Survey". Economic Development and Cultural Change, 32(2): 255-298

[16] Aldrich, J.H. and Nelson, F.D., 1984. Linear probability, logit and probit model: quantitative application in the social science-sera miller McCun, sage pub.Inc, University of Minnesota and Iola, London

[17] Gujarati, D.N. 1995. "Basic Economics, $3^{\text {rd }}$ edition". McGraw-Hill,Inc: Newyork

[18] Motamed M. K and Singh B. 2003. "Correlation of Adoption of Improved Sericulture Practices". Indian Journal of Extension Education XXXIX (1 and 2):51-57

[19] Makokha, M., H. Odera, II.K.Martim, J.R. Okelabo and D.M.Iruria. 1999. "Farmers' Perception and Adoption of Soil Management Technologies in Western Kenya". African Crop Science Journal, Vol.7 (4)

[20] Rahman S. 2007. Adoption of improved technologies by the pig farmers of Aizawl district of Mizoram, India

[21] Ban, A.W, Van den and H.S Hawkins. 1996. Agricultural Extension Black well Science Ltd, UK

[22] Rogers, E.M. 1983. "Diffusion of Innovation. 3rd ed". New York: Free Press

[23] Yohannis Gebremedhin. 1992. The effect of conservation on production in the Andit-Tid area, Ethiopia; in: soil conservation for survival Lowa state university press

[24] Shiferaw, B. and Holden, S.T. 1998. " "Resource degradation and adoption of land conservation technologies by small holders in the Ethiopian highlands". Agricultural economics 18 (2), pp. 233-247

[25] IPMS, 2005. "Enterprise Gender Fact Sheet". Apiculture, Atsbi PLW, Tigray Region

[26] Yadav, J.s. 1982. Evaluation of agricultural extension. New Delhi: Concept publishing company

[27] Degnet Abebaw and Belay Kassa. 2001. "Factors influencing adoption of high yielding maize varieties in south western Ethiopia: An an application of logit”. Quart.J.interna.Agric.40(2):149-167)

[28] Melaku Gorfu. 2005. "Adoption and profitability of Kenyan top bar hive beekeeping technology: A study in Ambasel woreda of Ethiopia”. Unpublished M.Sc. Thesis, Alemaya University, Alemaya

[29] Lelisa Chalichisa. 1998. "The determinants of adoption, intensity and profitability of fertilizer use: The case of Ejere district, West Shewa zone". An M.Sc. thesis presented to the School of Graduate Studies of Addis Ababa University, Ethiopia

[30] Doss, C., W. Mwangi, H. Verkuijl, and H. de Groote. 2003. "Adoption of Maize and Wheat Technologies in Eastern Africa: A Synthesis of the Findings of 22 Case Studies". CIMMYT Economics Working Paper 03-01. Mexico, D.F.: IMMYT

[31] Cramb, R.A. 2003. "Processes Affecting the Successful Adoption of New Technologies by Smallholders". In: Hacker, B. (ed). Working with Farmers: The Key to the Adoption of Forage Technologies, pp.11-22. ACIAR Proceedings No. 95. 
Canberra: Australian Centre for International Agricultural Research

[32] Voh, J.P. 1982. A study of factors associated with the adoption of recommended farm practices in a Nigerian village. Agricultural administration, 9 (1), pp. 17-27
[33] Million Taddesse and Belay Kassa. 2004. "Factors influencing adoption of soil conservation measures in south Ethiopia: The case of Gununo area". J.Agric.and Rur.devel.in the Tropics and sub tropics. 105(1):49-62 